\title{
Socio-economic Characteristics of the Cashew Growers of Tamil Nadu - An Analysis
}

\author{
A. Anusuya ${ }^{1}$, P. Balasubramaniam ${ }^{1}$ and T. R. Sridevi Krishnaveni ${ }^{2 *}$ \\ ${ }^{1}$ Department of Agricultural Extension and Rural Sociology, TNAU, Coimbatore - 641003 \\ ${ }^{2}$ Institute of Agriculture, TNAU, Kumulur, Trichy - 621712, India \\ *Corresponding author
}

\section{Ke ywords \\ Cashew, Production 2018-19, Profile, Cashew growers, Tamil Nadu, Ariyalur, Cuddalore}

Article Info

Accepted:

17 June 2020

Available Online:

10 July 2020

\section{A B S T R A C T}

Cashew being a livelihood providing crop is widely being cultivated in India. Tamil Nadu contributes significantly to the national level production of Cashew. Thus this study was taken up to study the profile of the cashew growing farmers of Ariyalur and Cuddalore districts of Tamil Nadu. Ariyalur and Cuddalore district were purposively selected. Out of $19(6+13)$ blocks in the two selected districts, Andimadam block from Ariyalur and Panruti block from Cuddalore district were selected based on areas under cashew cultivation. Sample of 120 cashew farmers was selected based on proportionate random sampling method. Eighteen profile variables related to cashew farming were identified, analysed and reported in this study. The respondents were interviewed personally by a well-structured and pre-tested interview schedule. The data collected were analyzed using appropriate statistical tools. Majority of the respondents were old aged category and onethird of respondents had primary education level, farming as their occupation and comes under the medium level of the annual income category. Nearly half of the respondents were small to big farmers and they had a medium level of farming experience and also years of experience in cashew cultivation. About half of the respondents had a medium level of contact with extension agency, farm power status, social participation, innovativeness, credit orientation and scientific orientation. Most of the respondents had a medium level of mass media exposure and economic motivation. More than half of the respondents had a medium level of participation in training undergone for cashew cultivation and decision-making behaviour.

\section{Introduction}

Cashew that has "Brazil" as its origin was originally introduced into India by Portuguese in the 16th century. It could also be called the 'Gold Mine' of the wasteland. Cashew scientifically knows as Anacardium occidentale L., and often referred as wonder nut is the most processed and globally traded nut. Thus it has the greatest potential to empower farmers, rural women and rural youth by creating various employment opportunities in the processing sector. It also has the greatest potential to create foreign 
exchange through exports. The production of Cashew in India was found to be in increasing trend. However, the production could not meet the growing demand as it has a wider scope of use in food and savory industries.

Cashew is a well-known crop in the West coast since the 16th century. Being a droughttolerant and self-managing crop it is been widely cultivated across the world. First five countries leading in the production of cashew are Vietnam, India, Ivory Coast, Philippines and Benin.

Cashew was first introduced in India to cover bare hills and for soil conservation. The market potential and the commercial scope of Cashew was realised only after the 1950s. Various series of researches and extension activities have been taken up in the last decade to promote commercialisation. Entrepreneurs were involved in its cultivation by the distribution of nondescript seeds and seedlings, processing of fruits, kernel, shells etc. Cashew found the Indian soil more homely than its homeland.

Maharashtra tops first in terms of production among the other major cashew growing states of India followed by Andhra and Odisha. Tamil Nadu stands sixth in cashew production in the country. In India cashew was cultivated in about 1062.04 million ha. Commercial cultivation of cashew is taken up in eight states of our country mainly in west and eastern coast viz., Andhra Pradesh, Goa, Karnataka, Kerala, Maharashtra, Orissa, Tamilnadu and West Bengal. In addition, cashew is also grown in few pockets of Assam, Chhattisgarh, Gujarat, Meghalaya, Nagaland and Tripura. The Western coastal States, i.e., Goa, Kerala, Karnataka and Maharashtra in the west coast and Andhra Pradesh, Tamil Nadu, Orissa and West Bengal in the eastern coast of India, are the main producer of cashew nut in the country.
According to Venkattakumar (2009) Majority of the respondents in Maharashtra, Andhra Pradesh and Tamil Nadu were middle aged, whereas that of Kerala was old aged. Majority of the respondents in Maharashtra and Andhra Pradesh had middle to high school level education, whereas that of Kerala and Tamil Nadu had middle and high school level education respectively. The farming experience of the respondents was 22 to 24 , 23 to 24, 25 to 26 and 28 years in Maharashtra, Kerala, Andhra Pradesh and Tamil Nadu respectively. The average farm size of respondents was highest in Andhra Pradesh (10.6 ha) and lowest in Kerala (1.2 ha). The average farm size possessed by FSG was 2.5, 1.7 and 1.5 times that of FGG in Maharashtra, Kerala and Andhra Pradesh, respectively, except in Tamil Nadu. The average share of cashew to total area was highest in Tamil Nadu (77\%) and lowest in Maharashtra (40\%).

Balarubini (2010) revealed that majority of the cashew farmers $(57 \%)$ belonged to middle age category, followed by ( $31 \%$ and $12 \%$ ) old and young categories. Majority of the respondents had Middle education (30\%) followed by Illiterate $(18.3 \%)$.Primary education accounted to 17.50 percent ,higher education namely Secondary and Functionally literate education was found of the respondents $(13.30 \%$ and $10.80 \%)$.Collegiate education constitutes a very meagre percentage of 9.20 percent. Majority $(49.20 \%)$ of the respondents had farming + labour as their profession, followed by farming alone $(36.60 \%)$. While $(14.20 \%)$ of the respondents were farming + business. There were no respondents identified with services along with their farming activities. Majority of the respondents $(46.70 \%)$ had medium level i.e. above 5 to 10 years of farming experience. High level (41.60\%) of the respondents had above 10 years of farming experience. Exactly $(11.70 \%)$ of the 
respondents had low level up to 5 years of farming experience.

She also revealed that majority $(44.10 \%)$ of the respondents possess farm with high level farm power followed by medium $(28.40 \%)$ and low (27.50\%) levels of farm power status. Majority of the respondents belong to the medium category (44.20 percent) followed by high $(32.50 \%)$ and low $(23.30 \%)$ levels. The results show that nearly half of the respondents were found to possess medium level of innovativeness with regard to cashew cultivation.

Majority (36.70\%) of respondents possesses high level of scientific orientation followed by low $(32.50 \%)$ and medium (30.80\%) levels of scientific orientation. Majority $(38.40 \%)$ of the respondents had high level of economic motivation followed by $(32.50 \%)$ who had low level of economic motivation. Only $(29.10 \%)$ of the respondents had a medium level of economic motivation.

The Southern states of India experienced two major hits of cyclone over past years, nearly in same decades - Tsunami in the year 2006 and the Thane Cyclone in December 2011. The similarity of these two strokes is that both were preceded over a period of decades and resulted in the loss of man and properties, and dismiss of agricultural production of the region. Farmers largely depend on the cashew nut farming even after the devastating cyclone. It is still considered promising farming and offers an alternative livelihood means to farmers in the region. In this context, this paper is an attempt to explore the profile of the cashew growing farmers of Ariyalur and Cuddalore districts, the leading cashew producers in Tamil Nadu. The objective of the study is to study the profile of the cashew growers of Ariyalur and Cuddalore districts.

\section{Materials and Methods}

Among 37 districts in Tamil Nadu, Ariyalur and Cuddalore districts were ranked first and second in the area under cashew cultivation with $24800 \mathrm{Mt}$ and $18835 \mathrm{Mt}$ quantity of production respectively as per the data of Tamil Nadu Horticulture Department statistics report of the year 2018-19. Hence, these two districts were purposively selected for the study. Out of these 19 blocks together in two districts, Andimadam block from Ariyalur district and Panruti block from Cuddalore district are the two blocks selected based on the area under cashew cultivation. Totally fourteen villages were selected from selected blocks. Seven villages from each block were identified with the help of records from Assistant Director of Agriculture of each district where the area under cashew cultivation was more.

Cashew growers in the selected districts are considered as the respondents. The sample size of 120 cashew growers was selected for the study based on Proportionate random sampling. Accordingly, 60 samples from each block totally 120 samples were randomly selected from the identified 14 villages covering two selected blocks. The profile of the cashew growers has been studied under eighteen different parameters. The data collection was done with the use of a wellstructured and pre-tested interview schedule for the farmers. Statistical Package for Social Sciences (SPSS) was used for analysis and the interpretation of data.

\section{Results and Discussion}

In any extension study, it is inevitable to analyze the farmer's characteristics. This would give a clear picture of the farmer's background, in turn, will help in framing appropriate policy implications. Hence, basic details about one farmer's characteristics were collected, analyzed and presented hereunder. 
Age

Age has been considered as a factor, as it may reveal the mental maturity of an individual to make decisions. Therefore it has been included in this study. Data collected on the age of the respondents were analyzed and presented in Table 3. The finding concludes that the old aged farmers were progressively involved in cashew cultivation than middle and young age farmers. This is due to the youth may be employed in other professions such as teachers, engineers and labours in industries. The findings are found to be inline with the findings of Saritha (2008).

\section{Educational status}

Education improves one's capability to cope up with different situations and also helps in taking correct decisions. The distribution of respondents according to their educational status was analyzed and presented in Table 3.

The reason behind their literacy from primary to higher secondary education might be due to that most of the villages in the study area were availed with educational facilities up to higher secondary education.

The graduated respondents got their degree or diploma in nearby towns. The poor people do not send their children to educational institutions and they remain illiterates. These would be the possible reasons for various educational levels observed in the study area. The findings are found to be in accordance with the findings of Jaisridhar (2009).

\section{Occupational status}

Occupational status decides the farmer's extent of involvement in farming. Agriculture as a full-time occupation makes an individual allocate more time in farming and helps in timely farm management activities. The respondents were categorized based on their occupational status in following Table 3.

It was observed from the findings that the majority of the respondents had farming as their only occupation. Some of the farmers were doing as wage earners around nearby industries. The findings are supported by the findings given by Anand (2011).

\section{Annual income}

Annual income is referred to as an important factor for the adoption of technologies and innovativeness. So it might include in the study as one of the variables. The respondents were classified based on their annual income as follows in Table 3.

The respondents get their income by selling the cashews in time when its price comes desirable leads to a minimum level of income attainment. Since it is an exported nut and demand in the market the respondents able to earn for their livelihood. This might be the reason for their income status.

\section{Farm size}

It is generally observed that farm size is another important factor in the acceptance or rejection of improved farm practices since the large size of the farm provides a favourable condition for the adoption of an innovation. Also, the farm size possessed by a farmer may exhibit the socio-economic conditions of the individual.

Table 3, indicates that more than half of the respondents $(53.00 \%)$ were small farmers, followed by nearly half of the respondents were big farmers. The respondents in Ariyalur district came under a nearly equal range of small $(56.70 \%)$ and big farmers (43.30\%). But Cuddalore district, farmers belonged to an equal percentage of small farmers $(50.00 \%)$ 
and big farmers $(50.00 \%)$. The farmers in the selected villages possess land area of more than 2 acres for farming. The findings are found to be in line with the findings of Rajkala (2004).

\section{Area under cashew cultivation}

It was included to know the extent of banana cultivation to which a cultivator could manage the farm for trial in a small area, initial huge investment and the risk to comfort.

It shows that the farmers grow cashew in small as well as in large areas. In Ariyalur district the farmers remain their land as fallow due to water scarcity and poor irrigation facility. Whereas, in Cuddalore district annual rainfall supports to some extent for farming.

\section{Farming experience}

Farming experience is one of the important key factors to carry out farming in a successful manner. The responses were collected and analyzed which are presented in the following Table 3. Majority of the farmers had farming as their major occupation and they had practised farming from their early days itself. So, they have a maximum level of farming experience.

\section{Experience in cashew cultivation}

Farming experience in cashew cultivation means the number of years of experience possessed by an individual in cashew cultivation. This helps the farmers in decision making, understanding the new technologies as well as acceptance or rejection of new technologies in cashew production. The respondents were categorized into low, medium and high based on their farming experience.
Since cashew cultivation is carried out in those areas for about four generations brings the experience in cashew cultivation at maximum levels. This might be the reason for their experience in cashew cultivation. These findings are in accordance with the findings of Suganthi (2004).

\section{Extension agency contact}

Extension agency contact refers to the contact of the farmers with the extension workers about farming who helps the farmers to learn new technologies and in management practices. The extension workers visit the villages under cashew cultivation to help the farmers periodically. This might be the reason for their medium level of extension agency contact. The findings are found to be in line with the findings of Jaisridhar (2009).

\section{Farm power status}

It refers to the material possession of the farmers which helps in the adoption of technologies and effective farming. The reason might be due to most of the farmers were availed with the sprayer, disc plough, country plough for their farm management practices. Some of the farmers possess tractor as their own. Others hire the implements from the agriculture department or from other farmers for their farming practices.

\section{Social participation}

Social participation helps the farmers in knowledge gain and skill improvement in farming practices. The reason behind their social participation level was the farmers do not participate actively in the regulated market, co-operative society as leader or member. The old-age farmers were continuing their participation from the early days. The findings are in accordance with the findings given by Rajkala (2004). 


\section{Mass media exposure}

This was the prime key factor for the farmers to get their first-hand knowledge about new cultivation technologies, newly arrived machines or varieties. This helps the farmers to get knowledge level and spread the new technologies to the farmers shortly in a prescribed way. The respondents possess television in their household which helps them to exposure. Majority of the respondents may have a habit of reading newspaper as their daily activity. The farmers also read agricultural magazines and attend the training and meetings. This helps them to interact with mass media. The findings are supported by the findings given by Jayanthi (2013).

\section{Innovativeness}

Innovativeness is an indicator of behavioural change among farmers which leads to acceptance of the technologies earlier than other members of the social system. This might be due to the experienced farmers would continue farming as in traditional way and they are not ready to take risk and huge investment in the new thing.

In Cuddalore district, the Thane effect and credit facilities help the farmers to adopt new techniques earlier than in the old days. This might be the reason behind their innovative behaviour.

\section{Credit orientation}

Credit orientation helps the farmers in gaining interest in adopting new things in farming and it may help farmers in critical stage to continue farming. This might be due to the farmers avail the subsidy from Horticultural development scheme and the respondents might have also availed credit support Thane flood relief schemes and measures.

\section{Scientific orientation}

Scientific orientation is a forerunner to farmer's innovativeness as stated by Rogers and Shoemaker (1971). Extension workers always aim to implant scientifically knowledge in the minds of the farmers. Since cashew is a cash crop the farmers would follow the scientific technologies after they satisfied with the existing output. Once they got satisfied they would adopt it easily. The findings are supported by the findings given by Karpagam (2012).

\section{Economic motivation}

The ultimate aim of every human is it earns more whatever may be their occupation. Farmers are also included in the same category. It might be due to their tendency to get a lump sum and lucrative income in a year. With these expectations and with their consistent motivation, they would have preferred cultivating cashew, despite risks and other disaster factors.

\section{Trainings undergone for cashew cultivation}

Training is the key factor for the farmers to understand the technology and decide to adopt in their farms. The trainings attended by the farmers regarding farming practices help the respondents to enhance knowledge level and attitude to adopt it.

The farmers did not show any interest in attending the training progress. The farmers attend training when it was carried out in their respective block or village as a one-day training programme. The farmers in Cuddalore district had attended more training than the farmers in Ariyalur district. The reason might be due to the interest of farmers in attending the programme was more in Cuddalore district than in Ariyalur district. 


\section{Decision-making behavior}

Decision-making behaviour is viewed as the most important factor for the farmers to decide the adoption of technologies in their farm. The cashew is being cultivated in rainfed areas. Hence, the farmers were not ready to make decisions to implement new things. They just follow the traditional and nearby farmers practices.

In conclusion, the cashew industry in India is largely an export-oriented industry which employs a large amount of manpower to process the nuts. It was only from the early twentieth century that the commercial value of cashew kernel for export and foreign exchange earnings were realized. However, the Indian processing industry has long been dependent on imported cashew nuts. The degree of import dependency has been increasing over time, especially since the mid1980s. This increasing dependency is attributed to the failure of domestic raw nut production to catch up with the growing demand for cashew kernels from both within and outside the country. Majority of the respondents belonged to old age group thus more policy interventions, technical supports, credit supports has to be framed from the government side to encourage and bring more youth into cashew farming. Majority of the respondents were found to be functional literates or with a primary level of education. Thus the extension methods have to be simplified with single window access. Moreover, in this modern era of internet, the contents and modules related to cashew farming or information and forecast disseminated online and through ICT tools have to be simplified in the regional languages and with more illustrations. More action-oriented images and videos could be used for the transfer of technology through online mode.

Table.1 Cashew nut global production statistics for the top twenty countries, 2017-18

\begin{tabular}{|c|l|c|c|c|}
\hline S. No. & \multicolumn{1}{|c|}{ Country } & $\begin{array}{c}\text { Production } \\
\text { (tones) }\end{array}$ & $\begin{array}{c}\text { Production } \\
\text { Percentage (\%) }\end{array}$ & $\begin{array}{c}\text { Yield (Metric } \\
\text { tones/ha) }\end{array}$ \\
\hline $\mathbf{1 .}$ & Viet Nam & 2663885 & 44.90 & 9.4 \\
\hline $\mathbf{2 .}$ & India & 785925 & 13.25 & 0.8 \\
\hline $\mathbf{3 .}$ & The Ivory Coast & 688000 & 11.60 & 0.4 \\
\hline $\mathbf{4 .}$ & Philippines & 228612 & 3.85 & 8.0 \\
\hline $\mathbf{5 .}$ & Benin & 215232 & 3.63 & 0.3 \\
\hline $\mathbf{6 .}$ & United Republic of Tanzania & 171455 & 2.89 & 0.3 \\
\hline $\mathbf{7 .}$ & Mali & 167621 & 2.83 & 4.2 \\
\hline $\mathbf{8 .}$ & Guinea-Bissau & 150934 & 2.54 & 0.6 \\
\hline $\mathbf{9 .}$ & Brazil & 141418 & 2.38 & 0.3 \\
\hline $\mathbf{1 0 .}$ & Indonesia & 136402 & 2.30 & 0.3 \\
\hline $\mathbf{1 1}$ & World & 5932507 & 100 & 1.0 \\
\hline
\end{tabular}

Source: Food and Agriculture Organization, 2020 
Table.2 Area, production and yield of major cashew growing states of Tamil Nadu, 2017-18

\begin{tabular}{|l|c|c|c|c|}
\hline \multicolumn{1}{|c|}{ State } & $\begin{array}{c}\text { Area } \\
(\mathbf{0 0 0} \mathbf{~ h a})\end{array}$ & Production (000MT) & Production Percentage (\%) & Yield (Kg/ha) \\
\hline Maharashtra & 191.45 & 269.44 & 32.98 & 1378 \\
\hline Andhra Pradesh & 186.78 & 116.92 & 14.31 & 600 \\
\hline Odisha & 193.99 & 98.59 & 12.07 & 513 \\
\hline Karnataka & 129.07 & 89.45 & 10.95 & 672 \\
\hline Kerala & 92.81 & 88.18 & 10.79 & 962 \\
\hline Tamil Nadu & 142.28 & 71.03 & 8.69 & 478 \\
\hline Goa & 58.25 & 34.26 & 4.19 & 561 \\
\hline West Bengal & 11.36 & 12.96 & 1.59 & 681 \\
\hline Chhattisgarh & 13.70 & 9.83 & 1.20 & 900 \\
\hline Gujarat & 7.25 & 6.50 & 0.80 & 393 \\
\hline Jharkhand & 14.83 & 6.13 & 0.75 & 812 \\
\hline Meghalaya & 8.58 & 6.12 & 0.75 & 432 \\
\hline Tripura & 4.25 & 3.45 & 0.42 & 1028 \\
\hline Pondichery & 5.00 & 2.16 & 0.26 & 360 \\
\hline Assam & 1.05 & 1.13 & 0.14 & \\
\hline Nagaland & 0.50 & 0.54 & 0.07 & 0.04 \\
\hline Manipur & 0.90 & 0.32 & & \\
\hline
\end{tabular}

Source: The Directorate of Cashewnut \& Cocoa Development (DCCD), 2018

Table.3 Profile of Cashew growers of Ariyalur and Cuddalore districts $(\mathrm{N}=120)$

\begin{tabular}{|c|c|c|c|c|c|c|c|}
\hline \multirow[t]{2}{*}{ S. No. } & \multirow[t]{2}{*}{ Category } & \multicolumn{2}{|c|}{$\begin{array}{c}\text { Ariyalur } \\
(\mathrm{n}=60)\end{array}$} & \multicolumn{2}{|c|}{$\begin{array}{c}\text { Cuddalore } \\
(n=60)\end{array}$} & \multicolumn{2}{|c|}{$\begin{array}{c}\text { Total } \\
(\mathbf{n}=\mathbf{1 2 0})\end{array}$} \\
\hline & & No & $\%$ & No & $\%$ & No & $\%$ \\
\hline \multicolumn{8}{|l|}{ Age } \\
\hline 1 & Young & 7 & 11.70 & 10 & 16.70 & 17 & 14.20 \\
\hline 2 & Middle & 11 & 18.30 & 13 & 21.70 & 24 & 20.00 \\
\hline \multirow[t]{2}{*}{3} & Old & 42 & 70.00 & 37 & 61.70 & 79 & 65.80 \\
\hline & Total & 60 & 100 & 60 & 100 & 120 & 100 \\
\hline \multicolumn{8}{|c|}{ Educational status } \\
\hline 1 & Illiterate & 12 & 20.00 & 14 & 23.30 & 26 & 21.70 \\
\hline 2 & Functionally literate & 3 & 5.00 & 0 & 0 & 3 & 2.50 \\
\hline 3 & Primary education & 18 & 30.00 & 14 & 23.30 & 32 & 26.70 \\
\hline 4 & Middle education & 10 & 16.70 & 8 & 13.30 & 18 & 15.00 \\
\hline 5 & Secondary education & 12 & 20.00 & 17 & 28.30 & 29 & 24.20 \\
\hline 6 & Higher secondary education & 2 & 3.30 & 4 & 6.70 & 6 & 5.00 \\
\hline 7 & Collegiate & 3 & 5.00 & 3 & 5.0 & 6 & 5.00 \\
\hline
\end{tabular}




\begin{tabular}{|c|c|c|c|c|c|c|c|}
\hline & Total & 60 & 100 & 60 & 100 & 120 & 100 \\
\hline \multicolumn{8}{|c|}{ Occupational status } \\
\hline 1 & Farming and Services & 5 & 8.30 & 1 & 1.70 & 6 & 5.0 \\
\hline 2 & Farming and Business & 6 & 10.00 & 5 & 8.30 & 11 & 9.2 \\
\hline 3 & Farming and Wage earner & 5 & 8.30 & 7 & 11.70 & 12 & 10.0 \\
\hline 4 & Farming alone & 44 & 73.30 & 47 & 78.30 & 91 & 75.80 \\
\hline & Total & 60 & 100 & 60 & 100 & 120 & 100 \\
\hline \multicolumn{8}{|c|}{ Annual income } \\
\hline 1 & Upto Rs 35,000/- & 5 & 8.34 & 1 & 1.70 & 6 & 5.00 \\
\hline 2 & Rs 35,000 to $90,000 /-$ & 50 & 83.33 & 48 & 80.00 & 98 & 81.66 \\
\hline 3 & Above Rs 90,000/- & 5 & 8.33 & 11 & 18.30 & 19 & 15.84 \\
\hline & Total & 60 & 100 & 60 & 100 & 120 & 100 \\
\hline \multicolumn{8}{|c|}{ Farm size } \\
\hline 1 & Marginal & 0 & 0 & 0 & 0 & 0 & 0.00 \\
\hline 2 & Small & 34 & 56.70 & 30 & 50.00 & 64 & 53.30 \\
\hline 3 & Big & 26 & 43.30 & 30 & 50.00 & 56 & 46.70 \\
\hline & Total & 60 & 100 & 60 & 100 & 120 & 100 \\
\hline \multicolumn{8}{|c|}{ Area under cashew cultivation } \\
\hline 1 & Less than 5 acres & 35 & 58.30 & 25 & 41.70 & 60 & 50.00 \\
\hline 2 & $5.01-10$ acres & 4 & 6.70 & 2 & 3.30 & 6 & 5.00 \\
\hline 3 & More than 10 acres & 21 & 35.00 & 33 & 55.00 & 54 & 45.00 \\
\hline & Total & 60 & 100 & 60 & 100 & 120 & 100 \\
\hline \multicolumn{8}{|c|}{ Farming experience } \\
\hline 1 & (Low) Upto 10 years & 0 & 0 & 8 & 13.30 & 8 & 6.70 \\
\hline 2 & (Medium) 11-20 years & 11 & 18.30 & 16 & 26.70 & 27 & 22.50 \\
\hline 3 & (High) Above 20 years & 49 & 81.70 & 36 & 60.00 & 85 & 70.80 \\
\hline & Total & 60 & 100 & 60 & 100 & 120 & 100 \\
\hline \multicolumn{8}{|c|}{ Experience in cashew cultivation } \\
\hline 1 & Low & 9 & 15.00 & 10 & 16.70 & 19 & 15.84 \\
\hline 2 & Medium & 41 & 68.30 & 43 & 71.70 & 84 & 70.00 \\
\hline 3 & High & 10 & 16.70 & 7 & 11.70 & 17 & 14.66 \\
\hline & Total & 60 & 100 & 60 & 100 & 120 & 100 \\
\hline \multicolumn{8}{|c|}{ Extension agency contact } \\
\hline 1 & Low & 22 & 36.70 & 6 & 10.00 & 28 & 23.34 \\
\hline 2 & Medium & 35 & 58.30 & 44 & 73.30 & 79 & 65.84 \\
\hline 3 & High & 3 & 5.00 & 10 & 16.70 & 13 & 10.82 \\
\hline & Total & 60 & 100 & 60 & 100 & 120 & 100 \\
\hline \multicolumn{8}{|c|}{ Farm power status } \\
\hline 1 & Low & 0 & 0.00 & 12 & 20.00 & 12 & 10.00 \\
\hline 2 & Medium & 59 & 98.34 & 40 & 66.70 & 99 & 82.50 \\
\hline 3 & High & 1 & 1.66 & 8 & 13.30 & 9 & 7.50 \\
\hline
\end{tabular}




\begin{tabular}{|c|c|c|c|c|c|c|c|}
\hline & Total & 60 & 100 & 60 & 100 & 120 & 100 \\
\hline \multicolumn{8}{|c|}{ Social participation } \\
\hline 1 & Low & 11 & 18.30 & 10 & 16.70 & 21 & 17.50 \\
\hline 2 & Medium & 35 & 58.30 & 50 & 83.30 & 85 & 70.80 \\
\hline \multirow[t]{2}{*}{3} & High & 14 & 23.30 & 0 & 0 & 14 & 11.70 \\
\hline & Total & 60 & 100 & 60 & 100 & 120 & 100 \\
\hline \multicolumn{8}{|c|}{ Mass media exposure } \\
\hline 1 & Low & 8 & 13.30 & 7 & 11.70 & 15 & 12.50 \\
\hline 2 & Medium & 42 & 70.00 & 45 & 75.00 & 87 & 72.50 \\
\hline 3 & High & 10 & 16.70 & 8 & 13.30 & 18 & 15.00 \\
\hline & Total & 60 & 100 & 60 & 100 & 120 & 100 \\
\hline \multicolumn{8}{|c|}{ Innovativeness } \\
\hline 1 & Low & 14 & 23.30 & 4 & 6.70 & 18 & 15.00 \\
\hline 2 & Medium & 34 & 56.70 & 32 & 53.30 & 66 & 55.00 \\
\hline 3 & High & 12 & 20.00 & 24 & 40.00 & 36 & 30.00 \\
\hline & Total & 60 & 100 & 60 & 100 & 120 & 100 \\
\hline \multicolumn{8}{|c|}{ Credit orientation } \\
\hline 1 & Low & 13 & 21.70 & 11 & 18.30 & 24 & 20.00 \\
\hline 2 & Medium & 47 & 78.30 & 41 & 68.30 & 88 & 73.34 \\
\hline 3 & High & 0 & 0.00 & 8 & 13.30 & 8 & 6.66 \\
\hline & Total & 60 & 100 & 60 & 100 & 120 & 100 \\
\hline \multicolumn{8}{|c|}{ Scientific orientation } \\
\hline 1 & Low & 13 & 21.70 & 8 & 13.30 & 21 & 17.50 \\
\hline 2 & Medium & 38 & 63.30 & 35 & 58.30 & 73 & 60.80 \\
\hline 3 & High & 9 & 15.10 & 17 & 28.30 & 26 & 21.70 \\
\hline & Total & 60 & 100 & 60 & 100 & 120 & 100 \\
\hline \multicolumn{8}{|c|}{ Economic motivation } \\
\hline 1 & Low & 11 & 18.30 & 11 & 18.30 & 22 & 18.34 \\
\hline 2 & Medium & 44 & 73.30 & 36 & 60.00 & 80 & 66.66 \\
\hline 3 & High & 5 & 8.30 & 13 & 21.70 & 18 & 15.00 \\
\hline & Total & 60 & 100 & 60 & 100 & 120 & 100 \\
\hline \multicolumn{8}{|c|}{ Training undergone for cashew cultivation } \\
\hline 1 & Low & 7 & 11.70 & 5 & 8.30 & 12 & 10 \\
\hline 2 & Medium & 38 & 63.30 & 38 & 63.30 & 76 & 63.30 \\
\hline \multirow[t]{2}{*}{3} & High & 15 & 25.00 & 17 & 28.30 & 32 & 26.70 \\
\hline & Total & 60 & 100 & 60 & 100 & 120 & 100 \\
\hline \multicolumn{8}{|c|}{ Decision making behaviour } \\
\hline 1 & Low & 11 & 18.30 & 5 & 8.30 & 16 & 13.34 \\
\hline 2 & Medium & 29 & 48.30 & 47 & 78.30 & 76 & 63.34 \\
\hline \multirow[t]{2}{*}{3} & High & 20 & 33.40 & 8 & 13.30 & 28 & 23.32 \\
\hline & Total & 60 & 100 & 60 & 100 & 120 & 100 \\
\hline
\end{tabular}


Majority of the respondents has farming as their main occupation, medium level of annual income and were found to be small farmers, who cannot bear risks. Thus utmost care has to be taken to remove market risk and production risk to make farming profitable to them. As the majority of the respondents have a medium to a higher level of farming experience, they might have acquired vast knowledge from their ancestors with regard to cashew cultivation. Thus it could be documented and validated for rationality and could be popularised with other cashew growing farmers. Majority of the respondents had a medium level of extension agency contact, hence, more opinion leaders have to be identified, and frequent propaganda, demonstrations, field visits have to be organised to increase the extension agency contact.

As the majority of the respondents possess low to medium level of farm power status, resources could be collectivised, government farm machinery hiring centres could be opened to support the farmers. Smaller and simple techniques have to be evolved that has a good level of innovation attributes for the farmers to readily adopt it. Majority of the respondents have a medium level of social participation thus participatory technology development and implementation methods have to be involved. The concept of producer organisations could be promoted among the farmers to increase the voluntary participation of the farmers. nearly half of the respondents have a medium level of mass media exposure and medium level behaviour of innovativeness. Thus new technologies could be easily popularised among these farmers. Majority of the have a medium level of credit and scientific orientation thus more technologies with sound scientific base has to be developed for the benefit of the farmers. As the majority of the respondents have a medium to a strong desire for the economic motivation technologies to improve the quality and quantity of the produces has to be concentrated to increase the income of the farmers. Majority of the respondents have undergone a medium level of training with respect to cashew cultivation and medium to high level of decision-making behaviour. Thus their decision with regard to production aspects was found to be independent.

\section{References}

Acchukatla, M. and Srinivasan, G. AN economic analysis of cashew value chain in Cuddalore district of Tamil nadu. International Journal of Research and Analytical Reviews, 6(1), 472-475.

Anand, K. 2011. Study on Critical Analysis on Adoption of Dry Land Technologies, Unpub. M.Sc(Ag.) Thesis, Agricultural College and Research Institute, TNAU, Coimbatore.

Jaisridhar, P. 2009. Study on Adoption and Marketing Behaviour of Maize Growers. Unpub. M.Sc. (Ag.) Thesis, TNAU, Coimbatore.

Jayanthi, M. 2013. An analytical study on awareness, Knowledge and adoption of management technologies in maize among farmers to minimize aflatoxin contamination. Pub.M.Sc (Ag.)Thesis. TNAU, Coimbatore.

Karpagam, P. 2012. Technology Adoption and Marketing Behaviour of Turmeric Growers. Unpub. M.Sc.(Ag.) Thesis, Agricultural College and Research Institute. TNAU, Coimbatore.

Murugamani, P., and Ravi, G. (2015). An Assessment on Cashew Nut Production in Cuddlore District, Tamil Nadu. International Journal of Business and Economics Research, 1(1), 1-9.

Nayak, M., and Paled, M. (2018). Trends in area, production, yield and exportimport of cashew in India an economic analysis. International Journal of 
Current Microbiology and Applied Sciences, 7(12), 1088-1098.

Rajkala, A. 2004. Training Needs and Distance Education Preferences of Commercial Crop Growers on Post Harvest Practices. Unpublished M.Sc (Ag.)Thesis, TNAU, Coimbatore.

Saritha, C. 2008. Cashew production in Perambalur district of Tamil Nadu - A critical analysis. Unpub. M.Sc. Thesis. Tamil Nadu Agricultural University. Coimbatore.

Suganthi, N.S. 2004. Technological gap in Cashew production - A critical analysis.
Unpub. M.Sc. Ag thesis. Tamil Nadu Agricultural University, Coimbatore.

Venkattakumar, R. (2016). Socio-economic factors for cashew production and implicative strategies: An overview. Indian Research Journal of Extension Education, 9(3), 55-62.

http://www.cashewinfo.com/more_news.aspx ?pageid=Dtcashew2_101819 Accessed on 15.06.2020

http://www.fao.org/faostat/en/\#data/QC Accessed on 15.06.2020

https://dccd.gov.in/Content.aspx $?$ mid=1075\&t $\mathrm{id}=1$ Accessed on 15.06.2020.

\section{How to cite this article:}

Anusuya, A., P. Balasubramaniam and Sridevi Krishnaveni, T. R. 2020. Socio-economic Characteristics of the Cashew Growers of Tamil Nadu - An Analysis. Int.J.Curr.Microbiol.App.Sci. 9(07): 1790-1801. doi: https://doi.org/10.20546/ijcmas.2020.907.205 